\title{
Design of Force Meter for Traction Unit
}

\author{
Gita Aprilyana, Endang Dian Setioningsih, Triwiyanto \\ Department of Electromedical Engineering Poltekkes Kemenkes, Surabaya \\ Jl. Pucang East Jajar No. 10, Surabaya, 60245, Indonesia \\ aprilyanag@gmail.com,diancholik@gmail.com,triwiyanto123@gmail.com,
}

\begin{abstract}
Force gauge is an instrument used to measure the force on the traction unit. The purpose of this study is made a force gauge meter which used during traction operation. The main component of this force gauge meter is Atmega 328, HX711 module and Loadcell type $\mathrm{S}$ sensor. The mikrokontroller Atmega 328 is the main board. Loadcell type $\mathrm{S}$ used to detect the force of traction, and the module HX711 is used to amplify the output of the loadcell sensor. In this study, the measurements were performed in the hospital. The error of this design is $0.01 \%$ and $\mathbf{4 . 8 \%}$ for minimum and maximum, respectively. The force gauge designed portable and comes with a battery indicator.
\end{abstract}

\section{Keywords-Force Gauge; Traction Unit; Microcontroller; Loadcell; HX711}

\section{INTRODUCTION}

Traction is a technique used to treat joint dysfunctions such as stiffness, joint hipomobilitas reversible and pain. The principle of traction is interesting prisoners applied to the body, the legs, pelvis or spine and pull prisoners applied in the opposite direction is called the counter traction,

Study Global Burden of Disease (GBD) provide evidence of the impact of musculoskeletal conditions and highlights the significant burden of disability associated with this condition. In 2016 GBD study, musculoskeletal conditions are the second highest contributor global disability. Lower back pain remains a major cause of disability since it was first measured in 1990 . While the prevalence of musculoskeletal conditions vary by age and diagnosis. $20 \%-33 \%$ of people worldwide are living with painful musculoskeletal conditions. A recent report from the United States shows that one in two American adults living with the condition muskuloskeletal, an amount equal to those suffering from respiratory diseases, cardiovascular or other chronic diseases. For subjects with unilateral cervical radiculopathy [1], mechanical cervical traction with nerve mobilization is more effective in improving pain, functional disability and severity of radicular symptoms.

Step traction work[2] skeletal is Pin (Steinman or pin or wire $\mathrm{k}$ Denham thick) should be placed bikortik and secured properly in order to avoid mobilization of cortical bone, which can cause cortical defects that can lead to fractures in the region. After insertion, the pin is connected to the staple at both ends and put under pressure. Staples then connected to a rope, and a broken limb is placed on a special Zuppinger support with hips at about $45^{\circ}$ of flexion. The main reason for this is the use of traction prevention of possible damage to the neurovascular and skin lesions, especially in patients who suffer a fracture. Constant tensile force given by the applied load contribute to maintaining alignment of the limbs and fractures.
Effective force for traction static and discontinuous generally [3] 31,8kg ranged up to $68.0 \mathrm{~kg}$, an average of about $45 \mathrm{~kg}$. Judovich shows the importance of using sufficient force to achieve mechanical effects lumbar traction. Using cadaver and living subject, Judovich determine that $54 \%$ of the weight of the body segments is necessary to overcome the resistance between the table surface and body treatments. The lower body segment, under L3, weighs about $49 \%$ of the total weight. Therefore, the tensile force must exceed $26 \%$ of the total weight to affect the lumbar spine.

Given the important role sufficient traction to overcome health problems, it is necessary to check the function of traction is by doing calibration procedure using FORCE GAUGE. This is in accordance with PERMENKES No. 542015 that every medical devices used in health care and health facilities more must be tested and / or calibrations regularly by the Testing Center of Health Facility or Institutional Testing Healthcare Facilities (Minister of Health Regulation No. 54 / Menkes / Per / II / 2015 ).

Based on the analysis above, the objective of this study is to design a force meter for the traction unit. This design will use load cell type $\mathrm{S}$ sensor and displays the results on the Liquid Crystall Display.

\section{MATERIALS AND METHODS}

\section{A. Experimental Setup}

This study uses a traction subject to a maximum load of 45 $\mathrm{kg}$. Sampling was carried out consecutively starting $5 \mathrm{~kg}$ loads up to $45 \mathrm{~kg}$ with 5 times the data retrieval

\section{1) Materials and Tools}

This study uses a sensor Load cell Type $\mathrm{S}$ with a maximum capacity of $100 \mathrm{~kg}$ model of PSD-S1. Load cell sensor attached to a hook pulley traction. Components used to use ATmega 328 as a microcontroller, Module HX711 as Analog to Digital Converter load cell sensor. 


\section{2) Experiment}

In this study, the measurement used a traction unit with the setting of the load 5, 10, 15, 20, 25, 30, 35, 40 and 45 .

\section{B. The Block Diagram}

Load cell sensor reading towing load that is set on the appliance traction. The data read by the load cell is still in the form of voltage, it is necessary to use $\mathrm{h} \times 711$ to change the data in the form of voltages into digital data. The digital data is processed through Arduino which will be displayed on the LCD display. Changing button is used to convert kilograms into newton or vice versa. LCD display also shows the battery indicator is processed through Arduino.

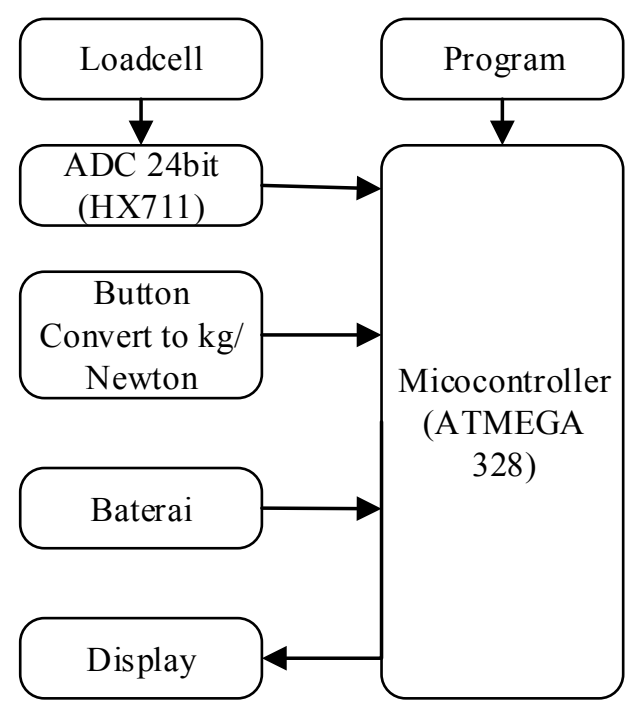

Fig. 1. The block diagram of the Force Gauge

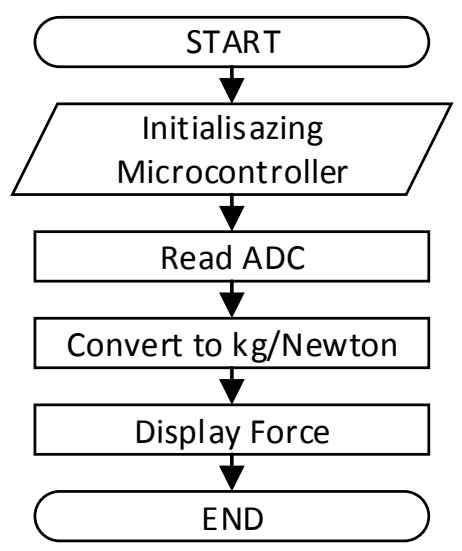

Fig. 2. The flowchart of the Arduino Program

\section{The Flowchart}

Arduino program runs like a flowchart Fig. 2. The program starts from the initialization of microcontroller and ADC readings, convert units of $\mathrm{kg} /$ Newton. After that, the results from the sensor readings will appear on the LCD display.

\section{The Analog Circuit}

It is important in the manufacture of this module is a schematic of the circuit as in Fig. 3 (microcontroller), Fig. 4 (instrumentition amplifier). The circuit used to process the analog data into digital data. The data will be processed using arduino

\section{1) Microcontroller}

Microcontroller circuit as shown above to get input from $\mathrm{hx} 711$ which connected with load cell sensor type S.

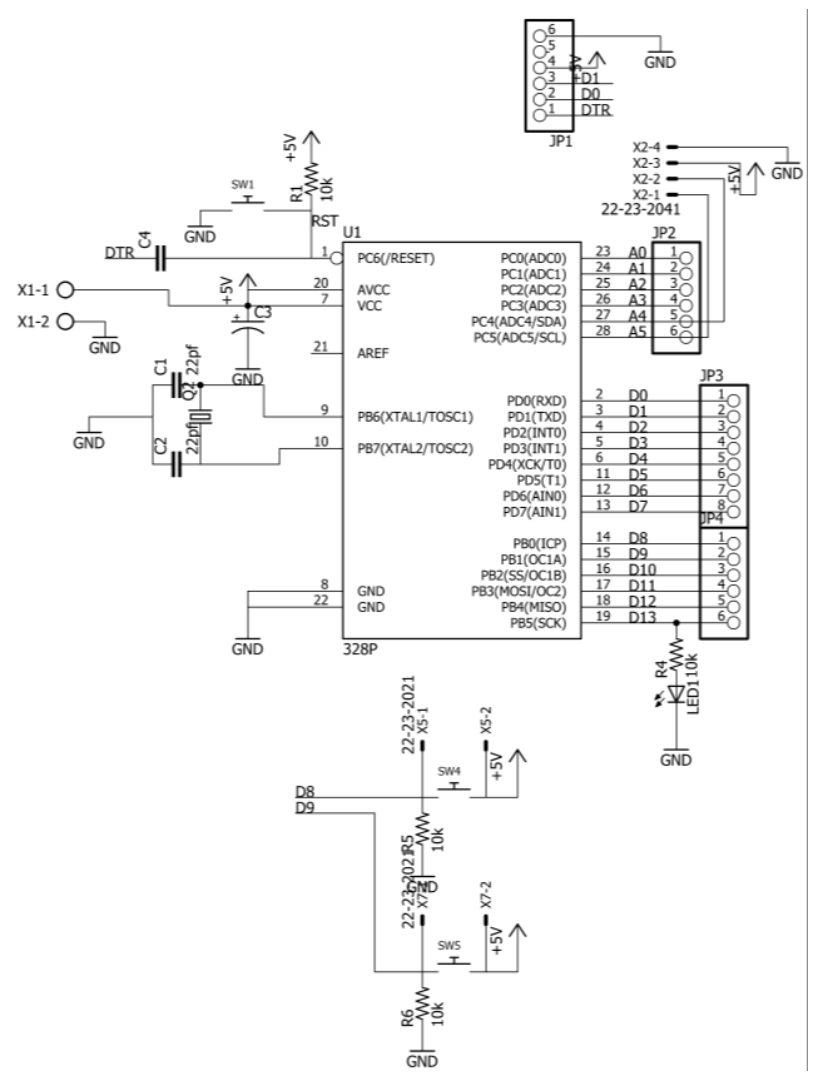

Fig. 3. microcontroller

\section{2) Instrumention Amplifier}

HX711 modules connected to the microcontroller by connecting the microcontroller pin to pin DOUT D2 and D3 to the SCK pin.

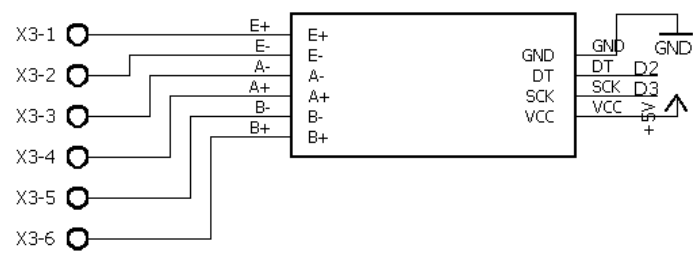

Fig. 4. instrumentation amplifier 


\section{RESULTS}

In this study the force gauge has been tried on a traction apparatus. The results of the comparison module with traction units obtained error value below $10 \%$.

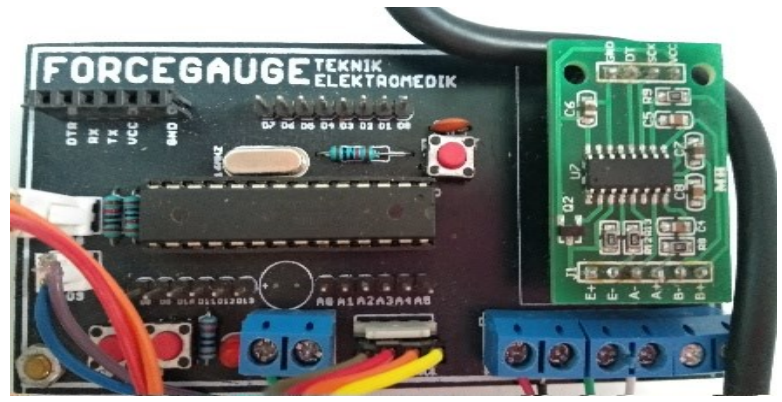

Fig. 5. The microcontroller design

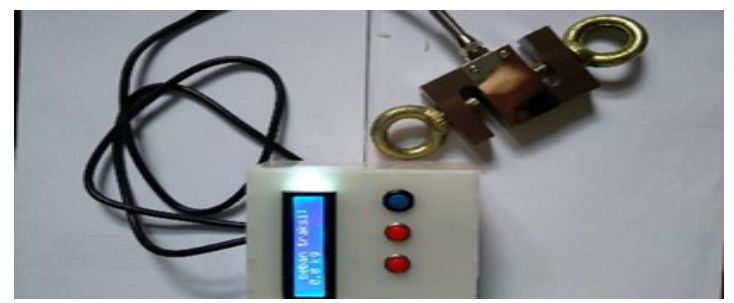

Fig. 6. Loadcell sensor type $\mathrm{S}$

\section{1) The Force Gauge Design}

Images of the analog and digital force gauge can be seen in Fig. 6 and Fig. 7. The Board consists of atmega 328 microcontroller as the microcontroller IC and Module HX711 as ADC for sensor loadcell. Digunagan loadcell sensor that is type $\mathrm{S}$ with a maximum weight of $100 \mathrm{~kg}$.

\section{2) The Listing Program for Arduino read sensor loadcell}

In this journal arduino program divided by 2 , which is a program read sensor and the low battery indicator program.

Listing program 1. The program to send the sensor to the microcontroller

\begin{tabular}{l} 
\#include "HX711.h" //You must have this library in your \\
arduino library folder \\
\#define DOUT 2 \\
\#define CLK 3 \\
HX711 scale(DOUT, CLK); \\
float calibration_factor = 42640; \\
void loop () \\
$\left\{\begin{array}{l}\text { scale.set_scale (calibration_factor); // Adjust to this } \\
\text { calibration factor } \\
\text { float result = scale.get_units (); }\end{array}\right.$ \\
\hline
\end{tabular}

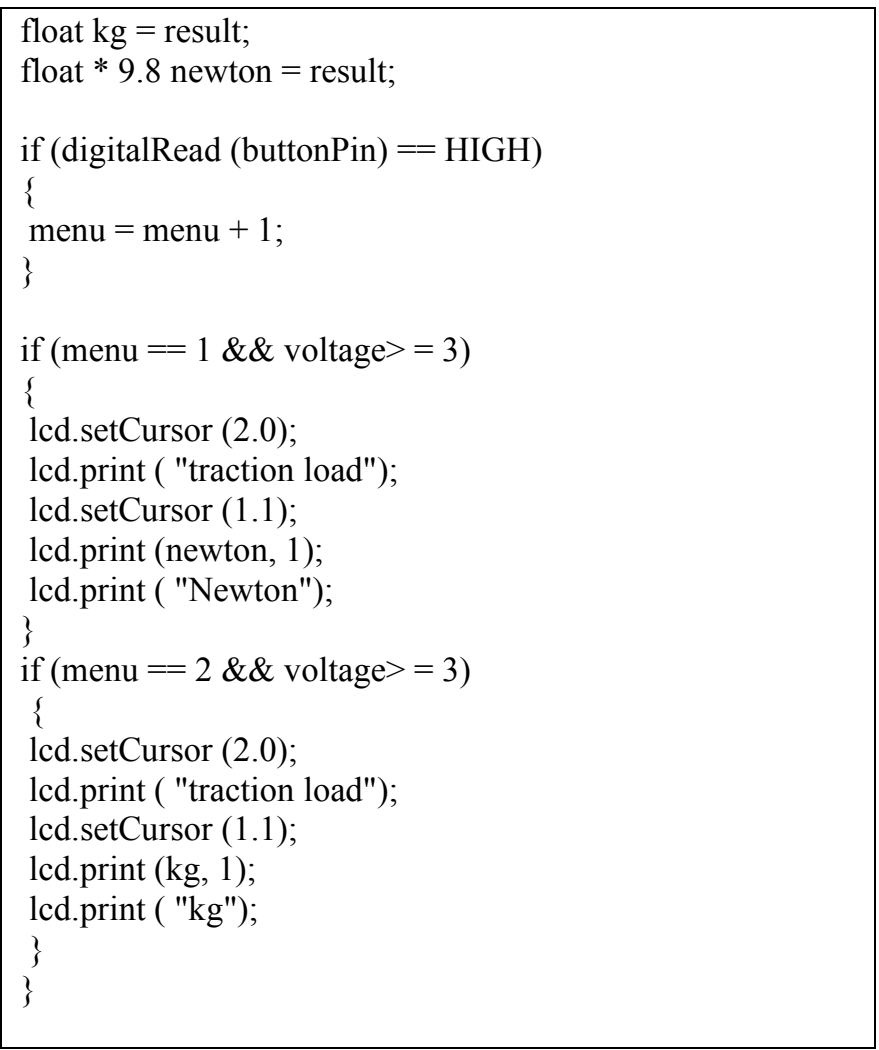

3) The Listing Program for Arduino low battery indicator The voltage of the battery affect the working of the microcontroller in the reading sensor, this module is equipped with a low battery indicator so that we will be exhausted battery charging Dapa done first.

Listing Program 2. Program depleted battery indicator

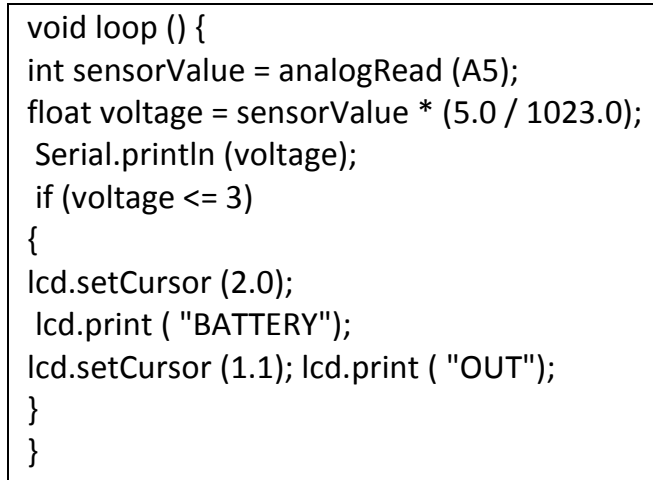


4) The result of lodcell output measurement by setting the traction

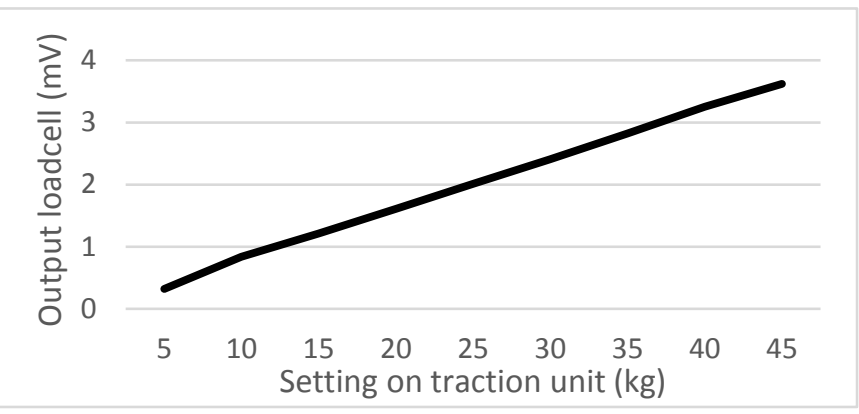

Fig. 7. Loadcell output measurement chart

\section{5) Measurement error}

The error value is obtained by comparing the value of the settings on traction with the value listed on the display module.

TABLE I. ERROR OF MEASUREMENT

\begin{tabular}{ccc}
\hline Data & $\begin{array}{c}\text { Setting Traction } \\
(\mathrm{kg})\end{array}$ & \%Error \\
\hline 1 & 5 & 4.8 \\
\hline 2 & 10 & 2.8 \\
\hline 3 & 15 & 3.4 \\
\hline 4 & 20 & 3.2 \\
\hline 5 & 25 & 2 \\
\hline 6 & 30 & 1 \\
\hline 7 & 35 & 0.6 \\
\hline 8 & 40 & 0.01 \\
\hline 9 & 45 & 0.06 \\
\hline
\end{tabular}

\section{DISCUSSION}

Based on the above voltage measuring any increase in the load voltage value of load cell output also increased. The increase in voltage of about 0.1 per kilogram.

The measurement results display on the tool force gauge compared with traction unit to detect the load pull in traction. Values obtained from measurement error between the traction module that is a load of $5 \mathrm{~kg}$ of $4.8 \%, 10 \mathrm{~kg}$ load of $2.8 \%, 3.4 \%$ load $15 \mathrm{~kg}, 20 \mathrm{~kg}$ load of $3.2 \%, 2 \%$ load $25 \mathrm{~kg}, 30 \mathrm{~kg}$ load of $1 \%$,

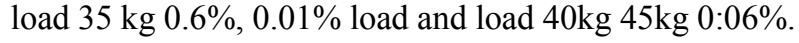

\section{CONCLUSSION}

Based on the results of the discussion and goals can be concluded that the circuit module and the module $\mathrm{hx} 711$ microcontroller can control the system properly. The force gauge can be used for measuring the pulling force on the traction unit. Load measurement using loadcell sensor type $\mathrm{S}$ displayed on the LCD $16 \mathrm{X} 2$.

\section{REFERENCES}

[1] H. Sharma and N. Patel, "Effectiveness Of Tens Versus Intermittent Cervical Traction In Patients With Cervical Radiculopathy Quick Response code," vol. 2, no. 6, pp. 787-792, 2014.

[2] C. Biz, I. Fantoni, N. Crepaldi, F. Zonta, L. Buffon, M. Corradin, A. Lissandron, and P. Ruggieri, "International Journal of Orthopaedic and Trauma Nursing Clinical practice and nursing management of preoperative skin or skeletal traction for hip fractures in elderly patients : a cross-sectional three- institution study," Int. J. Orthop. Trauma Nurs., vol. 32, no. October 2018, pp. 32-40, 2019.

[3] G. I. Pellecchia, "Lumbar Traction : A Review of the Literature," vol. 20, no. 5, pp. 3-8, 1994.

[4] PCE Instruments, “Operation Manual force gauge,” Alicante, 2019.

[5] L. Electronic, "Force gauge," Taipei, 1989, pp. 0-2.

[6] Chattanooga group, "Service manual traction," Lewisville, 2006. 